\title{
22
}

\section{Trans-Tasman stories: Australian Aborigines in New Zealand sealing and shore whaling}

\author{
Nigel Prickett \\ Auckland War Memorial Museum, Auckland, New Zealand \\ nprickett@aucklandmuseum.com
}

\section{Introduction}

Soon after the establishment of the English convict settlement at Sydney in 1788, New Zealand's first sealers landed at Dusky Sound in 1792 (Smith 2002:11), alerted to the presence of seals there by the journal of Captain Cook who visited in 1773 during his second voyage to the Pacific (Beaglehole 1961:135). The first sealing on Bass Strait islands took place in 1798 (Ling 1999:327). Exploitation of subantarctic islands began in 1804 at the Antipodes group (Smith 2002:12). Everywhere, big early catches soon declined. Nonetheless, seal numbers in southern New Zealand were sufficient to maintain an industry into the early 1830s (Smith 2002:12), with gangs dropped off along the coast from vessels out of Sydney, or in the 1820s by boat from Foveaux Strait. As relationships developed with Maori, especially with Maori women, many sealers stayed on to make a new life in New Zealand.

The first shore whalers set up in New Zealand in the late 1820s at Preservation Inlet at the southwest of the South Island and at Tory Channel, Cook Strait. Many sealers who had made a home in New Zealand moved easily to the new industry. Throughout the 1830s and in the early 1840s, shore whaling was New Zealand's biggest industry, exporter and employer. New Zealand's early sealing and whaling industries were part of the commercial interests of Sydney merchants, who pursued anything that might turn a profit, also including New Zealand timber and flax (Phormium tenax), and beche-de-mer, sandalwood and pork from tropical Pacific islands. Sydney's ocean frontier was central to Australia's early commercial and capital development.

This paper derives from a historic-archaeology research project on New Zealand shore whaling, supported by the Marsden Fund of the Royal Society of New Zealand and carried out in collaboration with Ian Smith, of the Anthropology Department, University of Otago. The main research focus has been Banks Peninsula where the 1840s Oashore whaling station was excavated in January-February 2004, and the Hawke's Bay district (Hawke Bay) where Te Hoe on Mahia Peninsula was investigated in 2005. Shore whaling at these places was part of 
a sealing and whaling industry which played a significant role in early colonial economic and social history on both sides of the Tasman (Figure 1).

With Australia the source of most New Zealand shore whalers, it is not surprising that one and two generations after the First Fleet sailed into Port Jackson some were of Aboriginal descent. Their fathers were convicts or ex-convicts. Mothers came from the many tribes that lived at or near the Australian coast and were largely dispossessed and dispersed early in the process of colonisation. The best known among them was Thomas Chaseland, whose convict father arrived in New South Wales in 1792 and later settled in the Hawkesbury district near Sydney. Chaseland was sealing at Foveaux Strait from c. 1824 and later whaled at several southern stations. Notable Hawke's Bay whalers from the mixed-race sealing communities of Bass Strait and Kangaroo Island were George Morrison, Edward Tomlins and Samuel Harrington.

\section{Thomas Chaseland}

The father of the New Zealand sealer and whaler, also called Thomas Chaseland, was convicted at Middlesex, on October 26 1791, aged 19, for an offence given as 'Capital Respite' (Colonial Secretary, Convict Indents 1788 to 1798 . COD/9, State Records NSW) - i.e. it was a capital offence (unstated) for which he received instead a life sentence. After time on a hulk, he arrived in Port Jackson on the Royal Admiral on October 71792 (Smee and Provis 1981). In July 1824, 'Thomas Chasling' applied for land not periodically flooded, as was his 30 acres at Lower Portland Head on the Hawkesbury River near Windsor (Colonial Secretary, Fiche No 3082:829, State Records NSW). He stated that he had arrived in the colony 'upwards of 31 years ago and [was] now settled upwards of 21 years', indicating he completed his sentence c. 1803.

Thomas Chaseland had several children with Margaret McMahon, beginning with John, born c. 1798 (reported as 30 years of age in the 1828 census, where the family is listed as 'Cheeseling', with 'Chaseling' under 'other surnames'; State Records NSW). There followed Ann, Jane, Thomas, Louisa and Charlotte (Smee and Provis 1981). Thomas and Margaret were married at St Matthew's Church, Windsor, on November 29 1812, with five of their children baptised the same day (McDougall pers comm. 2008). Margaret died in 1815 aged 38 (NSW Pioneers Index 1788-1988, State Records NSW). Thomas and Margaret's son Thomas was born in 1807 (Baptisms Index, NSW Registry of Births, Deaths and Marriages; State Records NSW), and is recorded in the 1828 census (State Records NSW) as 22 years of age and living at Lower

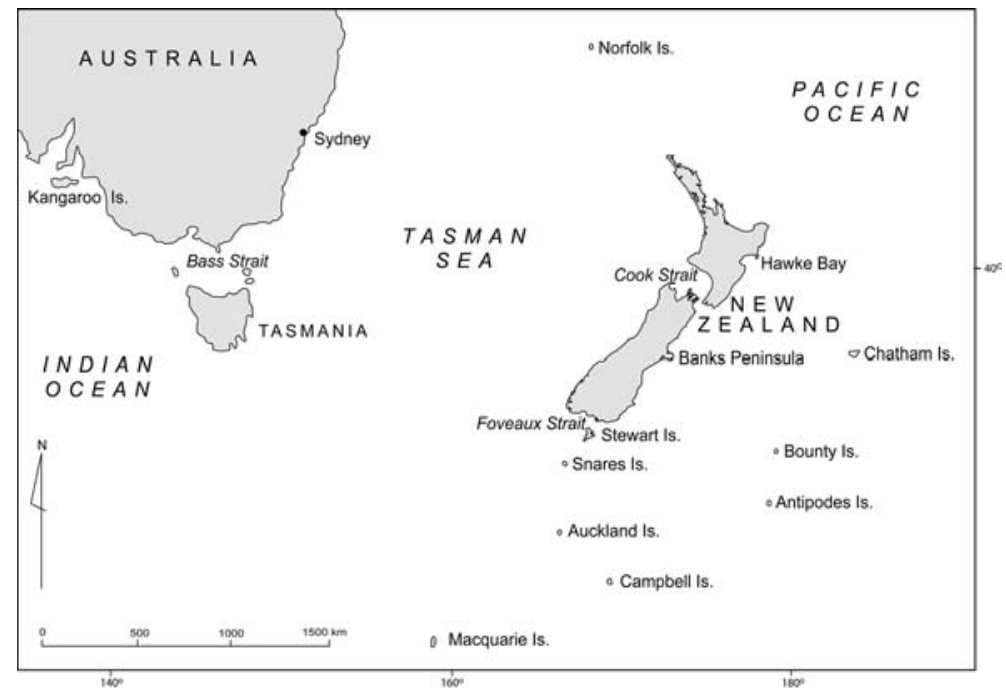

Figure 1. New Zealand and southeast Australia. 
Portland Head (i.e. Windsor). Thomas senior died in 1847 at Wilberforce, New South Wales (Smee and Provis 1981). Thomas, born in 1807, died on October 301878 - at Wilberforce, like his father (Smee and Provis 1981).

The New Zealand Thomas Chaseland first appears in the crew list of the Jupiter (Captain Bunster), which left Sydney on August 61817 for Hobart, as 'Thomas Chaseling, son of a settler at Windsor by a native woman' (Cumpston 1970:44). The Society of Australian Genealogists (SAG) on-line 'NSW Ships' Musters 1816-1825' has Chaseland listed as a passenger on the Frederick and crew on the King George, both in 1818. 'Thomas Chaselin', 'Seaman', left Hobart for Port Dalrymple (Launceston) and Port Jackson on the Governor Macquarie on October 2 1819 (Crowther Port Certificate Book, L11, p. 71, Tasmanian State Archives). On October 7 1820 'Thomas Chaceland 23' left Sydney on the Glory for Port Dalrymple on a sealing voyage to the islands northwest of Australia (Cumpston 1970:54), which importantly gives his age. Ages are often given for younger seamen on crew lists at the time. Thomas was thus born c. 1797, 10 years before his half-brother of the same name, and a year before the birth of Thomas and Margaret's first child in 1798. The Glory returned to Sydney on January 131822 after 15 months, but details of the voyage and cargo are lacking (Cumpston 1970:54).

On April 9 1823, Chaseland left Sydney on the St Michael (Captain Beveridge) for New Zealand and Tonga (Cumpston 1970:70; Cumpston 1977:139; SAG on-line 'NSW Ships' Musters 1816-1825'). On January 25 1824, he sailed on the Nereus (Captain Emmett) from Sydney taking convicts to Port Dalrymple, arriving there on February 10 (Cumpston 1970:70, 1977:147; Nicholson 1983:94), and from there on a sealing voyage, because in May 1824 the Nereus, now under Captain Swindells, was back at George Town and Launceston with seal oil and skins from the 'Fishery/Sealing Is' (Cumpston 1970:70; Nicholson 1983:96), probably southern New Zealand. No later record of Chaseland has been found in crew or passenger lists out of Australian ports. Thus, although specific information is lacking, it is likely the Nereus left Chaseland at Foveaux Strait on this voyage. Important places in Chaseland's career in southern New Zealand are shown in Figure 2.

According to 1879 recollections of the whaler Edwin Palmer to Dunedin historian Dr T.M. Hocken, Chaseland was the headsman on sealing boats belonging to Sydney merchant (Robert) Campbell in Foveaux Strait in early 1826 (Begg and Begg 1979:300). On January 13 1827, Chaseland was on the Glory, in which Campbell had an interest, when it went ashore at Pitt Island in the Chathams (The Australian March 20 1827). Captain Swindells and some crew subsequently reached the Bay of Islands in a long boat. Chaseland and others reached New Zealand at Moeraki in an open sealing boat (Shortland 1851:153).

Herries Beattie, recorder of southern Maori lore, has accounts of the voyage from two Maori sources (given here from Church In press). An informant named Ellison states of Puna, wife of 'Tame Titirene' (Chaseland):

Her husband and she went to Chatham Islands \& were wrecked. They built a boat $\&$ put sufficient food on it $\&$ came back here. She was a great tohunga $\&$ pulled one of her hairs, said a karakia $\&$ put it in the sea, so they had a safe voyage and landed at Moeraki.

Mrs Walscott (Ema Karetai), told Beattie: 'Puna sat in the bow of his [Chaseland's] boat from Chatham Island karakia-ing to keep the storm down.' For southern Maori this was an important story about two notable individuals.

But Beattie (1919:219-220) has a less attractive story of Chaseland's relations with Maori when he and other sealers, provoked by a raid on their camp at Arnott Point in south Westland (Beattie has Arnett's Point) when one of their number was killed, attacked a Maori settlement in 


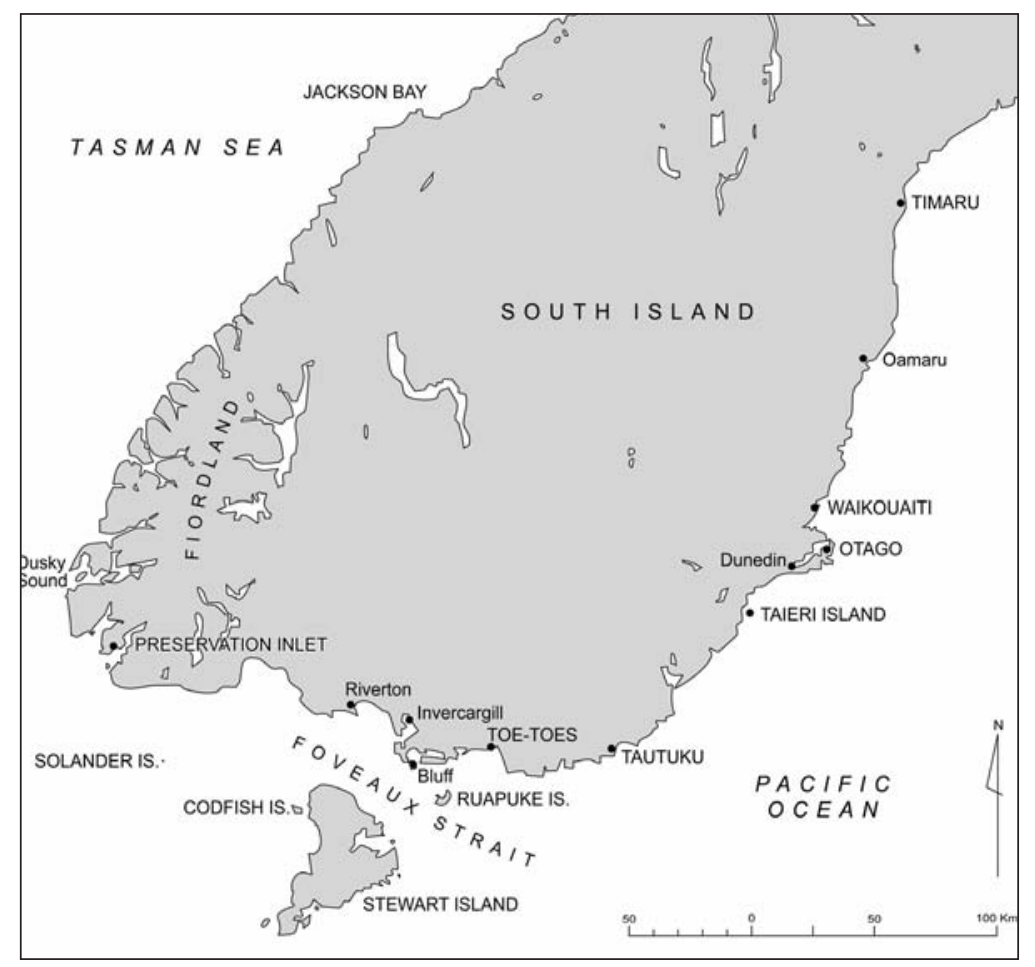

Figure 2. Southern New Zealand.

the vicinity of Okahu (Jackson Bay) or Arawhata. Several Maori were killed and a child named Ramirikiri, whose parents were killed, was left for dead by a berserk Chaseland who '... dashed her head on a rock'. But Ramirikiri survived and would later remind Chaseland of the event, who had nothing to say in reply. Another source has two sealers killed in the Maori raid and, from Chaseland's information on a map among papers of the survey ship HMS Acheron, an annotation that 30 Maori were killed in the reprisal (Starke 1986:xliv-xlv). The sealers then went to Anita Bay, Milford Sound, and attacked another Maori party, apparently killing all of them there or at Whareko, the next bay south. The Chaseland/Acheron map locates several tit-for-tat encounters between sealers and Maori in the 1820s.

Chaseland was among the first residents at Sealers Bay, Codfish Island (Whenuahou), after the island was set aside in the mid-1820s by Foveaux Strait chiefs for sealers and their Maori wives (Howard 1940:65; Anderson 1991:5; Middleton 2006:8-9). This was partly to help prevent just such conflict as described above between bands of sealers and Maori widely scattered around Foveaux Strait and northward. Doubtless it was useful for Maori to know where the sealers were, while sealers will have gained certainty for their settlement and security in numbers. This was important in 1833, when 200 Maori are said to have arrived on Codfish Island to 'exterminate' the sealers (Howard 1840:66-67). But the latter were warned by one of the Maori wives and met the war party on the beach armed with muskets, whereupon the sides agreed on peace, which was not broken afterwards.

On February 28 1831, Chaseland was one of three survivors of the Industry (Captain Wiseman), which left Codfish Island in a northerly gale for shelter and went down at Easy Harbour, Stewart Island (Howard 1940:85). Wiseman, 10 seamen and six Maori women were drowned (McNab 1913:86). The other survivors were Puna and George Moss who was living on Ruapuke Island. Howard says when the ship hit rocks entering the bay, Chaseland struggled to rescue Puna, but it was she who 'dragged the insensible Chaseland ashore', and the episode became the subject of a Maori song now lost. According to F. Hall-Jones (1944:157), Chaseland 
got Puna ashore then went back to rescue others, but hit his head on a rock, so Puna in turn rescued him. Differing accounts of the wreck and events leading to it are outlined by Middleton (2006:29-30). Also from his sealing days, Chaseland related how he was the only survivor of an attempted landing on one of two small islands (Green or Taieri) south of Cape Saunders (Shortland 1851:153-154).

When Sydney capitalists set up the first New Zealand whaling stations many Foveaux Strait sealers turned to the new industry. The first southern station was Bunn and Company's operation at Preservation Inlet from 1829 (Prickett 2002:19). Right whales calved in the bays and inlets of southern New Zealand from as early as April, the season continuing until about October. Chaseland had previous experience on sea-going whalers. The first record of his involvement in New Zealand is in 1835 when he and James Brown took 11 whales in 17 days from ToeToes at the mouth of the Mataura River (Shortland 1851:300). This was reported by Edward Shortland (1851:145) as 'the greatest feat of the kind ever performed in the country'. As there were no casks at the station, the oil was lost and the only product will have been whalebone. In 1836, Chaseland and Brown obtained 30 tuns (Shortland 1851:300), which is the last record of whaling at Toe-Toes.

In 1837, 'Chaseling' was 'chief headsman' at Preservation Inlet, where he was first to beat the boy Charles Denahan before Edward Palmer beat him with a rope's end, from which he died, leading to a manslaughter trial at Sydney (McNab 1913:204-220). In April 1838, Octavius Harwood, the Weller brothers' storekeeper at Otakou, issued Chaseland with whaling gear for the season, probably as manager at one of the harbour stations (Tod 1982:36). In September 1842, James Joss of Stewart Island wrote to Harwood that Chaseland had taken two boats to set up a 'new fishery' at Jackson Bay (Howard 1940:371), a locality he knew from sealing days. This suggests he was prospecting for the 1843 season, as unless the news was many months old, it was too late for 1842 . There was a whaling station at Jackson Bay, but whether it was established as early as 1842 and whether Chaseland whaled there both need confirmation. He was not at Jackson Bay in 1843, as in March that year he signed an agreement to whale at Waikouaiti with Stephen Smith and Thomas Jones (Tod 1982:93), and was in Waikouaiti in August that year at the height of the whaling season for his marriage to Puna (see below). Later in 1843, Chaseland accompanied Shortland (1851:141-164) on Johnny Jones' Scotia from Waikouaiti in his survey of Foveaux Strait settlements.

In 1844, Chaseland managed a three-boat, 25-man station at Taieri Island for Johnny Jones, taking 45 tuns of oil and two tons of whalebone (NZ Spectator and Cook's Straits Guardian February 12 1845). Dr David Monro, of Nelson, who accompanied Frederick Tuckett's expedition looking for a site for a proposed Scottish settlement in southern New Zealand, wrote on May 11844 that the party was '... hospitably entertained by a Mr. Chasland, the head man on the island, while his active Maori wife acquitted herself most respectably of the household duties of cooking and bed-making' (Hocken 1898:247; see Hocken 1898:215 for Tuckett's comments). In 1846, the two-boat, 18-man Timaru station under 'Chesland' took 43 tuns of oil and two tons of whalebone (NZ Spectator and Cook's Straits Guardian February 3 1847). Joseph (1903) tells of Chaseland being a partner of Palmer at Tautuku. If so, he was there some time between 1839 and 1846, as William Palmer was set up at Tautuku by Johnny Jones in 1839 and said himself he was eight years there, 'until the whales became scarce' (Evening Star July 4 1881). This has confirmation from 1847, being the first year the station is not listed in New Zealand production data (NZ Spectator and Cook's Straits Guardian January 8 1848), indicating it was closed by then.

From the above information, of variable quality, Chaseland was whaling at Toe-Toes in 
1835 and 1836, Preservation Inlet 1837, Otakou 1838, Jackson Bay 1842 (?), Waikouaiti 1843, Taieri Island 1844, Timaru 1846 and Tautuku in one or more of the missing years between 1839 and 1846. In 1851, he was taken on as pilot for HMS Acheron's survey of the West Coast sounds (Howard 1940:130).

Chaseland was renowned among Foveaux Strait sealing and whaling gangs for his 'great size and strength' and 'was considered the best whaler in New Zealand' (Shortland 1851:153). In 'Reminiscences of Early Days', published in The Otago Witness December 12 1906, L. Langlands says of Chaseland:

... his mother being an Australian gin, from whom, probably, he inherited his wonderful sight, was a large, heavy, clumsy-looking man, but wonderfully light on his feet, and, despite his bulk, very active; when fast to a whale, on relinquishing the steer-oar to go to the bow of the boat to use the deadly lance, he would run along the gunnel as active as an acrobat.

There are stories of his extraordinary eyesight, such as seeing a whale invisible to the master of the Amazon who had the advantage of a telescope (Howard 1940:392). Church (In press:128) gives other claims by his contemporaries of an ability to see nearly a mile underwater. Shortland describes him as 'a universal favourite owing to his excellent temper; never being quarrelsome under any circumstances' (Shortland 1851:153). F. Hall-Jones (1944:157) writes of his 'eagleeye, his uncanny knowledge of New Zealand waters, his almost super-human strength, courage, [and] prowess .... In 1856, aged nearly 60, he offered to fight the first Bluff constable in a trial of manhood (F. Hall-Jones 1944:159).

The best-known story of the legendary Tommy Chaseland relates to the naming of the South Otago headland 'Chasland's Mistake' (the Maori name is Makati; or Makate, see Roberts 1909). One version has him mistaking it in fog for Cape Saunders, which Joseph (1903) rightly thinks unlikely, given his knowledge of the coast and famous eyesight. Chaseland himself said that it tells of an occasion when, against orders, his gang attacked seals as soon as they made their seasonal return to that part of the coast, rather than leave them alone until settled, and that most therefore fled and were lost. Another version has Chaseland landing one evening but leaving the seals for the morning, by which time they had gone (Beattie 1948:10; J. Hall-Jones 1990).

Another story is from Tautuku (Joseph 1903). Whales were sighted one foggy June morning and boats launched after them. But when Chaseland made fast to a whale he was towed into the fog, and when he got close enough to use the lance the whale lashed out and destroyed the boat. Two Maori and a Pakeha were killed and Chaseland, Sam Perkins and a third Maori were left clinging to wreckage. After nearly an hour in the water and hidden from the other boats by fog, Chaseland stripped off and swam for the shore six miles away. The other two were then rescued, although the Maori died afterwards from exposure. Despite a search, Chaseland was not found and the other boats returned to Tautuku to report the loss. But late in the afternoon, he was seen after his long swim in the cold southern ocean, walking along the beach to the station, where he was revived by dry clothes and a pannikin of rum.

In his appetite for alcohol, too, Chaseland was legendary. Shortland (1851:152) saw him at Ruapuke Island drunk on 'sour wine' from a wrecked cargo and lying 'like a cask' on the bottom of their boat. According to F. Hall-Jones (1945:76-77), it was actually rum, part of the cargo of the Lunar wrecked at Waipapa Point. It had been brought to Ruapuke, but when all the men were drunk at the same time, the rum was hidden by the Maori women. Chaseland apparently knew where it was. In another story, Captain Stevens of the Otago, who had engaged Chaseland for a whaling voyage, found him drunk in a Dunedin hotel and lured him into a whaleboat to be taken to the ship only by the promise of rum applied as required on the way out (Langlands 
1906). When Stevens tried to ration the rum and told him to wait until they reached the next point in the harbour, Chaseland's reply was, 'Pull, and be to you', the incident giving its name to Pulling Point below Port Chalmers. In his liking for alcohol, he was no different from most sealers and shore whalers at the time.

The marriage of 'Thomas Chaseling' and 'Mary Puna' was formalised at Waikouaiti on August 141843 by the Rev. James Watkin (J. Hall-Jones 1990). They had no children. Puna was a relation of the Otago chief Taiaroa (Joseph 1903; Howard 1940:85), or his sister, according to Tuckett, who met her at Taieri Island in May 1844 (Hocken 1898:215). Begg and Begg (1979:278) give a short whakapapa showing Taiaroa and Puna as brother and sister, but Shortland's (1851:Table F) more extensive genealogical table does not name Puna. Whatever the relationship, Puna's ritual ability to ensure a safe passage from the Chatham Islands reflects and proclaims her high birth. Chaseland and Puna were together as early as January 1827, when they were wrecked on Pitt Island, and probably in 1826, when he lived at Codfish with other sealers and Maori wives, if not earlier. Puna died of influenza and was buried on January 61849 at Waikouaiti, aged 42 (McDougall pers comm. 2008).

On August 151850 at Ruapuke Island, Chaseland, then resident at Bluff, married Pakauhatu/ Pakawhatu (Margaret Anthony in the marriage register), daughter of Anthony Remond and Esther Pura. The register has his age as 47 (he was probably 53) and hers as 15 (Wohlers Register of Marriages Nos 4 and 5, Hocken Library, Dunedin), although there is information giving her birth date as February 20 1837, and therefore 13 when she married (McDougall pers comm. 2008). They were to have six children: Maria born in 1852, Thomas 1854, John 1856, Caroline 1861, William Henry c. 1864 and Margaret 1866 (McDougall pers comm. 2008).

Thomas Chaseland died on Stewart Island on June 51869 (J. Hall-Jones 1990). His name is remembered in Chasland's Mistake and the associated Chaslands district, and by Chasland's Point on The Neck, Stewart Island, marked on Captain Wing's 1844 chart (Howard 1940:124, 126) and under Schoolhouse Point on the latest NZMS 260 map sheet. Chaseland also contributed to New Zealand science when he found a pair of moa feet at Waikouaiti, reported by Walter Mantell (1872:95). Mostly, however, he is remembered as a huge presence and character in the early contact period in southern New Zealand.

\section{George Morrison}

George Morrison was the son of Patrick Morrison, of County Tyrone, Ireland, who was convicted in March 1792, aged 19, and arrived in New South Wales on the Boddington on August 71793 on a seven-year sentence (Principal Superintendent of Convicts, Bound Indents, 1786-1799, State Records NSW). Patrick was one of many convicts who made for the sealing grounds when they finished their sentence. Having suffered for long under the often brutal and generally brutalising convict regime, they may have wished for nothing more than to go somewhere they would be left alone and where there was the prospect, at least, of earning a living, and possibly a great deal more. A generation later, whaling stations on both sides of the Tasman would offer the same attractions.

The younger Morrison was born on August 121817 on King Island, Bass Strait (Figure 3), and baptised with his brother Charles, older by one year, on October 91821 at St Johns, Launceston, when the family was living at Georgetown on the Tamar estuary (Baptisms in the Parish of St Johns, Launceston, Microfilm RGD 32/1, 1170/1821, Tasmanian State Archives). In the baptism register, their mother is named 'Elizabeth' and described simply as 'A Native'. Patrick Morrison is likely to be the same as buried at Launceston on March 191824 after drowning, although his age given as 54 does not quite match 19 years in 1792 (Register of 
Burials, RGD 34/1, 1803-1838, 883/1824, Tasmanian State Archives). At the time, he is said to have been living at Launceston.

George Morrison may be the same as a Morrison in charge of a whaling party at Portland in 1837 (Townrow 1997:12), although he was 19 or 20 at the time, which is young for such a position. He first appears in New Zealand as whaling master at Macfarlane's fishery at Wairoa, Hawke's Bay (Figure 4), in its first seasons in 1844 and 1845 (NZ Spectator and Cook's Straits Guardian Febuary 22 1845, December 6 1845), possibly arriving to set up the station when men and stores were landed from Macfarlane's Kate in December 1843. This date is given as part of evidence in a court case arising from Morrison selling whalebone to a man named Crummer when the station's production rightfully belonged to Macfarlane as owner (NZ Spectator and Cook's Straits Guardian September 27 1845). Crummer and Morrison claimed that Morrison and others were at Wairoa setting up a 'share party' before Macfarlane first arrived at the end of 1843 . If so, this did not change Macfarlane's ownership of the fishery, although it does leave open the date of Morrison's arrival. The court found for Macfarlane. Morrison was at Wairoa just two seasons (NZ Spectator and Cook's Straits Guardian February 22 1845, December 6 1845) before managing Perry's Waikokopu station in 1846 (Wakefield 1848:193). In August 1849, his schooner Neptune was wrecked at Long Point on Mahia Peninsula (Ingram 1984:37). Later records of his New Zealand career have not been found.

\section{Edward Tomlins}

Edward (Ned) Tomlins was born at Cape Barren in 1813 to Samuel Tomlins of Kangaroo Island (Plomley and Henley 1990:103) and a woman whose name George Robinson of the Tasmanian Aboriginal mission gives as POOL.RER.RE.NER, or BULL.RUB, BULLROE, BULRA and BOOLROI (Plomley 1966:1002). Edward was baptised at St John's, Launceston, on January 221819 (Tipping 1988:197; Plomley and Henley 1990:103). His father was aged 20 when sentenced to seven years' transportation, reaching Sydney in 1803 on the Calcutta and Hobart on January 11804 (Index to Tasmanian Convicts, Tasmanian State Archives; Tipping 1988:317; Plomley and Henley 1990:103). He was discharged in 1809 (Tipping 1988:197) and was soon on the sealing grounds between Australia and Van Diemen's Land (Figures 1 and 3). Samuel Tomlins drowned in 1819 when the Jupiter was anchored at the Bay of Shoals, Kangaroo Island (Cumpston 1970:45; Plomley and Henley 1990:103).

His son is also given as Tomlinson and 'Edward Hanson', although according to Plomley (1966:1016), the latter may be an error, since it appears only in part of Robinson's journal which relies on a copy and where there are several apparently incorrect names. Robinson describes Tomlins in 1830 at Hunter Island as 'a fine stout well-made young man about eighteen years of age' (Plomley 1966:179). Plomley and Henley (1990:103) say he was $5 \mathrm{ft} 8$ inches $(1.73 \mathrm{~m})$ in height and stoutly built. George Dunderdale ([1898]:13) in 'The Book of the Bush' states that 'Black Ned was a half-breed native of Kangaroo Island'. In 1830, he was living on Hunter Island with 'NICK.ER.UM.POW.WER.RER.TER', or 'Mary', of Leven River or Ben Lomond, Tasmania (Plomley 1966:1018).

When Robinson visited in June 1830, the 'head man' of four Hunter Island sealers was Bay of Islands Maori 'John Witieye' (Plomley 1966:179), also probably an error, as elsewhere Robinson has MYTYE, MYTEE and MYET.EYE (Plomley 1966:1014). The name may have been 'Maitai'. The other men were Robert Drew (Rew or Rue, see Plomley 1966:1015), David Kelly and 'the half-caste youth, named Edward Hanson' (Plomley 1966:180; but see above). In December 1830, Tomlins was one of five Hunter Island men marooned on the Clarke Island 


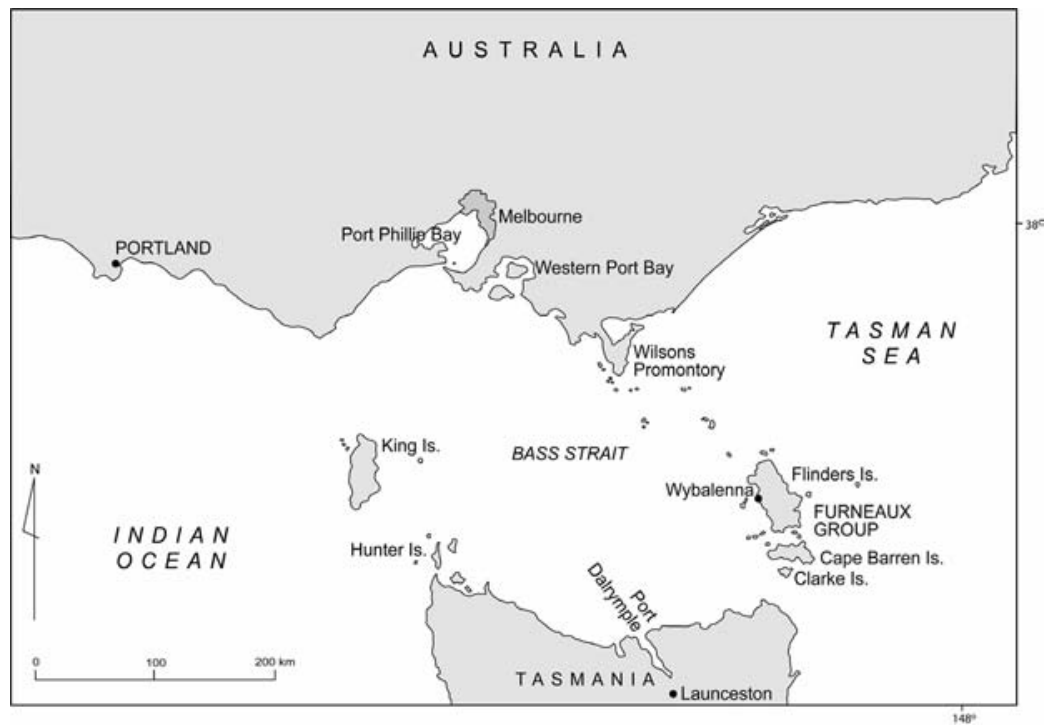

Figure 3. Bass Strait.

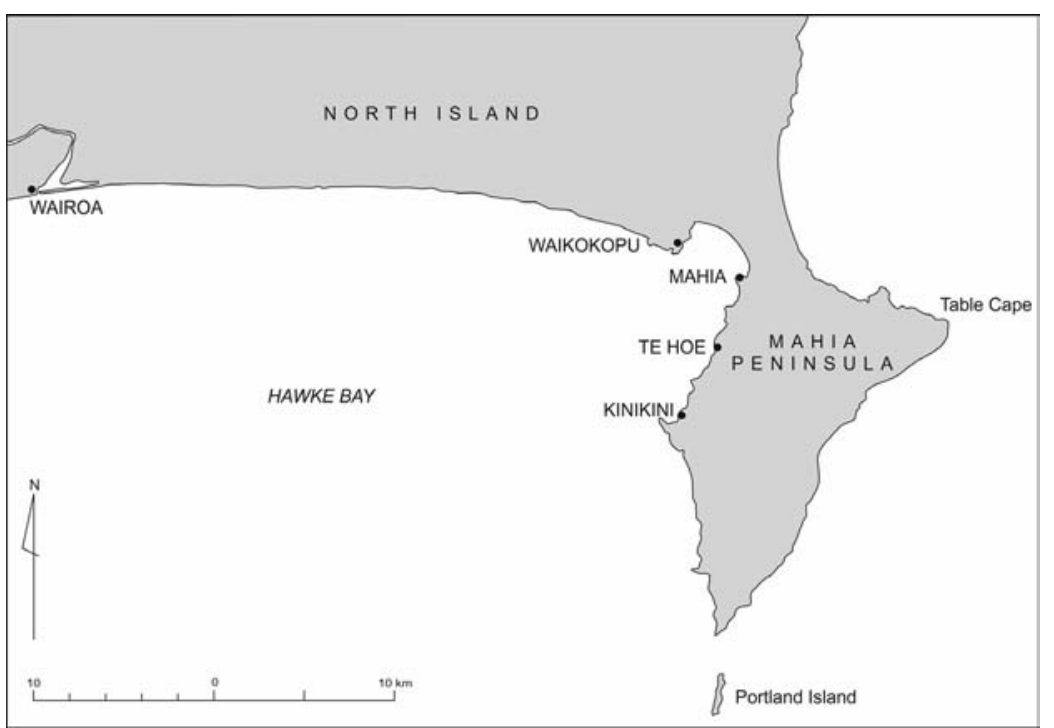

Figure 4. Northern Hawke's Bay.

reef when their boat was lost (Figure 3). Two disappeared trying to reach safety in a makeshift craft, the others living for eight days on seal meat and blood before being rescued (Plomley 1966:295-296).

In February 1832, Bulra arrived in Launceston from Kangaroo Island, where for years she had been living with a sealer named 'Young Scott' (Plomley 1966:801,1002). She went on to Hunter Island, probably because her son was there, but Edward left soon after on a whaling voyage to the 'western coast of New Holland', and may have sold or bartered his mother, who was soon living with John Dodson and then Robert 'Rew', both of them sealers and ex-convicts (Plomley 1966:1002). When Robinson returned to Hunter Island later in 1832, Bulra asked to be removed to the Aboriginal settlement on Flinders Island and was given up to him on August 17 (Plomley 1966:1002). At Flinders Island, she was probably at Lagoons until February 1833 and then at Wybalenna, when that settlement was established (see Birmingham 1992:129; Figure 3). In November 1832, Tomlins petitioned to have her returned to Hunter Island, but this was refused, Robinson advising: '... Tomlins is not a fit person to have charge of this woman 
he being wholly under the influence of the other sealers and himself addicted to drunkenness and immorality' (Plomley 1966:802). Bulra died on Flinders Island probably before September 1835 (Plomley 1966:1002).

Tipping (1988:317) states that Tomlins 'was an associate of William Dutton in the early days of whaling at Portland Bay and became a famous harpooner' (Figure 3). Nash (2003:91-92) has Dutton whaling for Launceston entrepreneurs Griffiths and Connolly in 1832 at Portland, which may have been the destination of Tomlins' whaling voyage early that year (see above). $\mathrm{He}$ is also likely to have been one of 24 men taken to Portland by the Henry in April 1833 (Cumpston 1970:120) for the second season. Dunderdale ([1898]:13) says that by 1835, Tomlins was 'looked upon as the best whaler in the colonies, and the smartest man ever seen in a boat'. On March 19 1836, he left Launceston as a passenger on the Thistle (Index to Departures 1817-1867, from an original record POL (Port of Launceston) 458/2, p. 21, Tasmanian State Archives), probably for the Portland fishery at that time of year. The Thistle was at Portland as early as 1834, initially to set up the Henty station in opposition to Dutton (Cumpston 1970:123-124).

On December 20 1836, 'Edward Tomlinson' was one of two headsmen on the barque Socrates (Captain Dutton), which left Launceston on a whaling voyage (POL 458/2, p. 56, Tasmanian State Archives). In early May 1836, the Socrates returned to Launceston from Portland with 23 tuns of sperm oil, with news that 'bay whaling' had commenced there (Chamberlain 1989:21). Thus, Tomlins at this time may have been whaling the year round, for sperm whales from the Socrates in summer and for right whales at Dutton's Portland station from autumn to October. Cumpston (1970:115-125) has an account of Griffiths and the productive Portland fisheries (see Nash 2003:91-94).

It is not known when Ned Tomlins arrived in Hawke's Bay. Information on his New Zealand career comes largely from 'An Old Colonist', thought to be F.W.C. Sturm, writing in the Hawke's Bay Herald in June 1868: 'Where all were drunkards, Ned Tomlins was notorious; he was a valuable man, and an able headsman.' In his 'Old Wairoa', Thomas Lambert (1925:368) describes Tomlins as 'said to be one of the best whalers that ever stepped into a boat' (apparently after Dunderdale), and recklessly generous, once giving away one of three sperm whales he had taken in exchange for a bucket of water. Lambert (1925:368) says he worked for Captain Mansfield and whaled out of Waikokopu and Kinikini. At Waikokopu, he probably whaled with Morrison, whom he may have known from Portland. Tomlins died there after a successful day's whaling. More drunk than others who were playing cards, he was turned out of a house, but insisted on trying to get back in. Finally, he was hit by the station owner, a man named Perry, and thrown from the door, later to be found dead outside. Perry himself read the burial service. This happened before Perry died of 'apoplexy' on the beach at Mahia in 1853.

Tomlins and Hipora Iwikatea of Mohaka had one son, also Edward Tomlins, who had three children, a girl Akenehi, a boy Tamati, and a second girl Hera. Hipora Iwikatea died on November 12 1900, her son Edward predeceasing her on December 151892 (Parsons pers comm. 2008).

\section{Samuel Harrington}

The Australian history of Samuel Harrington is more problematic. A published list of early 19th century sealer/Aboriginal liaisons in Tasmania has only one Harrington (Plomley and Henley 1990:64), who must logically be the same John Harrington said elsewhere in the same source to have lived in the Bass Strait islands with 'WORE.TER.NEEM.ME.RUM.NER.TAT.TE.YEN. NE', otherwise 'Bet Smith', who was abducted by him from Cape Portland as a child (Plomley 
1966:1020). Harrington was, of course, a convict, who, two days after being discharged at Sydney on May 25 1820, sailed on the Little Mary for Port Dalrymple and Bass Strait (Plomley and Henley 1990:82-83) and the freedom of the sealing grounds. He drowned at Gun Carriage Island (now Vansittart Island, at the eastern end of the strait, which lies between Flinders and Cape Barren Islands) about December 1824, after which Bet Smith was 'seized' by Thomas Tucker, who sold her to Thomas Beadon (Plomley 1966:1020), or she was 'claimed' by John Williams (Plomley and Henley 1990:83). According to Robinson, Tucker was among those active in shooting Aboriginal men at their fires and then abducting their women (Plomley 1966:1017).

Although the partner of John Harrington in the Plomley and Henley (1990:64) list is said to be from Van Diemen's Land, rather than Australia (Cape Portland), this does not necessarily rule out Bet Smith or this particular Harrington. There is, however, a 'half-caste' Maria Harrington recorded twice by Plomley and Henley (1990:63): in 1827 aged 10 and living in the household of James Holman, and in an 1831 list of 'half-caste' children in Launceston, 'aged about 17, a vagrant'. Maria cannot have been the child of a man who reached Tasmania in 1820, so there was one other Harrington/Aborigine liaison at least. Another John Harrington in Tasmania early enough to be the father of Maria, and perhaps Samuel, is listed among convicts brought from Norfolk Island in 1808 (Nobbs 1988:195), probably reaching Hobart on the City Of Edinburgh on October 5 that year (Nash pers comm. 2008).

'T. McD.' in The Lyttleton Times (July 6 1885) refers to Harrington at the time of a visit to Wairoa by Bishop Selwyn, Church of England archbishop of New Zealand, as follows:

One very powerful fellow, a half-caste Australian black, was known by the name of Shiloh. He was "cock of the walk" at the Wairoa, being a first-class boat-steerer, harpooner, fighter, fifty-two inches round the chest, and a hard drinker. These virtues retained him possession of the position he had gained.

The journal of Wairoa missionary the Reverend James Hamlin dates Selwyn's visit to December 1845 (Hamlin Journal, December 9 and 11 1845, Hocken Library). Harrington was thus under Morrison at Wairoa, raising the possibility that he and perhaps Tomlins as well, and other Australian whalers, all came with Morrison at the end of 1843, possibly from Portland. Lambert (1925:370) writes that Harrington was a 'Tasmanian half-caste' who whaled at Mahia, Kinikini and Waikokopu and for Joseph Carroll at Te Hoe.

Something of Harrington's style is told by a court case regarding an incident at Mahia in 1851, reported by boatsteerer Joseph Mason (Hawke's Bay Province, Donald McLean Papers, Folder 130A, Alexander Turnbull Library, Wellington). Harrington is said to have threatened and attacked his men, intending, it seems, to make them leave and break their contracts so he would not have to pay them out at the end of the season. This suggests he was owner of the station; otherwise, he presumably would not have had to bear the cost. Mason wrote to Donald McLean, as the only Justice of the Peace in the region, complaining that he had been 'most Barbarously ill treated and my life threatend by one Samuel Harrington in a most shoking maner and sent away without my wages'.

According to Mason, one day in October 1851, Harrington ordered the boat launched from his station with the purpose of going across the bay to Waikokopu for rum:

Some time after we arrived there he was intoxicated aboute 12 o'clock at night he came down to the Boat Swearing in a most awfull maner and Enquiring where Hooper another whaler was the answer was lying on the grass where drunken people in general lay, he ordered us to launch the Boat which we did, when a short distance on the water he got up as one deprived of all reason and Seized a Boat Spade used to cut up the Whale's Blubber, and a most deadly instrument. 
The boat with Harrington and two European and five Maori whalers aboard got home 'after a while and with much trouble'.

Next morning, Harrington:

... raving like a mad man took up an axx and threatening to kill all around. Struck one of the Natives on the Back but did not do him much hurt the Native runing at the time and he after him.

He then took up a tomahawk, swearing to kill anyone who opposed him. The whalers kept away from him, 'knowing that all our wages depended upon his honesty and being now to the amount of from $£ 21$ to $£ 30$ and upwards so that it appears that he did not wish to pay us ...'. Harrington then set fire to a house used by his Maori whalers.

The court case did not consider the violence, which was probably thought the business only of those involved. Instead, it set out to determine current whaling practice in order to establish the justice of Mason's claim. Four affidavits dated December 61851 are important in describing whaling practice in the bay at the time. The court's decision was for Mason to be paid out at a $1 \frac{1 / 4}{4}$ share, although this may not have ended the matter, as among the case papers is a note: 'Mason agrees to take the share of $1 \& 1 / 4$ which canot agree to pay', and initials which might be 'SWH'. Other cases heard the same day were Mason versus Carroll, seeking payment for the repair of a boat, and Stewart versus Mason for defamation and assault (McLean Journal, Vol. 4, p. 68, Alexander Turnbull Library), so Mason, too, may have been a difficult character.

Samuel John Harrington is listed in the 1858 Ahuriri and Hawke's Bay electoral roll as 'whaler' of Mohaka, in Hawke's Bay south of Wairoa, qualifying as a householder (Hawke's Bay Herald August 28 1858). He is listed under Mahia as a whaler in the first issue of Wises Directory, published in 1875 (Feilding ed 1875). He died at Wairoa on December 151875 (Hawkés Bay Herald December 17 1875).

\section{Aborigines in New Zealand sealing and shore whaling}

In Making Peoples, historian James Belich (1996:131-132) notes the importance of the sealing industry to early Maori/Pakeha contact in southern New Zealand. He goes on, 'Sealing also pioneered a Tasman world', and he describes sealers, whalers and seamen who did not distinguish between two sides of the Tasman in their activities, with Bass and Foveaux Straits and the subantarctic islands all being referred to as the 'Sealing Islands', in 'a joint past historians in both countries seem reluctant to recognise'. Sydney was for long one of New Zealand's most important cities and New Zealand one of Sydney's most important hinterlands (Belich 1996:134). Sealing and whaling industries developed capital needed for Australia's early economic growth and were among New Zealand's first significant commercial activities (see Steven 1965; Hainsworth 1972).

Tomlins, Morrison and Harrington came from the mixed-race sealing communities of Bass Strait and Kangaroo Island. Robinson describes how sealers shot Aboriginal men as they sat around their fires, and then abducted the women (e.g. Plomley 1966:966). Or women were traded by Aborigines themselves, from their own tribes or others from which they had been abducted (Ryan 1977:30-31). At first, women were made available for the sealing season only, but as sealers began to stay on throughout the year, so too did their 'wives'. By 1816, sealers each might have two to five women for sexual and domestic purposes. Robinson refers to them as 'slaves' (Plomley 1966:1008). In 1830, Tomlins' headsman at Hunter Island, the Maori 'John Witieye', had two women (Plomley 1966:180). Coastal tribes were devastated, Robinson reporting just three women with 72 men in Tasmania's northeast, also in 1830 (Plomley 1966:966).

Chaseland had a very different early history in the Hawkesbury district near Sydney. His 
father also was a convict. Nothing is known of his mother, who was probably from a local tribe. He was born a year before his father's first child with his European wife. It seems he was then brought up at Windsor with step-brothers and step-sisters. He is said to have been illiterate (J. Hall-Jones 1990). Were his father's other children also illiterate? In 1807, a half-brother was also named Thomas after his father, who clearly was more pleased with his black son in 1797 than he was 10 years later. Chaseland almost certainly left home before the first available record on the 1817 Jupiter crew list when he was already 20.

In the best contemporary account of New Zealand shore whaling, Edward Jerningham Wakefield (1845 I:311) identifies the men as ex-seamen, runaway convicts from New South Wales and Van Diemen's Land, and their descendants whom he knew as 'currency lads' and whom he greatly admired. But this term did not include those discussed here. In the language of the day, they were Australian or Tasmanian half-castes or 'New Holland blacks' - that is, they were identified as being of mixed race or by their Aboriginal parentage. When Australia was naming and identifying with its colonial-born and the country they were making their own, such men were on the margins. Thomas Chaseland's half-brother of the same name was 'currency' that he could never be.

But if 'half-castes' felt excluded from the new Australia, the main reason for moving to New Zealand was undoubtedly economic. The opportunity of making a living, and even doing well, was an attraction in any industry first to exploit a new resource - grasslands and gold are other important Australasian examples. The men introduced here were experienced in sealing or whaling or both. Chaseland was probably a sealing headsman from his first arrival. His leading role at Toe-Toes in 1835 tells of previous whaling experience. Tomlins had a big reputation in Australian whaling, while Morrison must have been experienced to have begun in New Zealand as manager at Wairoa. Harrington was 'cock of the walk' in his first or second year at Wairoa and was later station manager at Mahia - or owner, since he planned to benefit from driving his men off to avoid paying them out. Hawke's Bay drew whalers from districts of declining production on both sides of the Tasman as the last significant whaling region to be developed, the first season probably being 1837 (Prickett 2002:103).

Other factors may have come into decisions to move to New Zealand. Chaseland may have met Puna on a previous visit, encouraging him to make the move. Also, such men were used to the freedom and opportunity of Sydney's ocean frontier and New Zealand would have appealed to those used to life beyond the reach of government at Bass Strait and Kangaroo Island. In July 1847, Hawke's Bay missionary William Colenso wrote of a Wairoa informant describing local whalers as 'runaway soldiers and man-of-warsmen, convicts from New South Wales and Van Dieman's Land, who openly boast of their defiance of the Government' (Dinwiddie 1916:28).

Other Aborigines in New Zealand include one of five sealers picked up in 1813 after several years stranded on the rock that is Solander Island at the western entrance to Foveaux Strait (McNab 1907:149-150), and a Kangaroo Island woman and two-year-old child who survived the killing of a sealing gang from the General Gates by Maori at Stewart Island, then to live on their own for eight months before being rescued and returned to Sydney in April 1824 (Cumpston 1970:66; Richards 1995:35). A 'Tasmanian half-caste' known only as 'Darkie Coon’ whaled at Mahia and Wairoa, Hawke’s Bay (Lambert 1925:371). There are records of several others.

Maori also left home on sealing and whaling voyages. On October 23 1813, five were on the William and Ann at Sydney (Cumpston 1970:36). On the Glory out of Sydney for Port Dalrymple and the seal fishery on October 301819 was 'Jacky Miti (Myty)' (Cumpston 1970:53), likely to be the same as Tomlins' headsman on Hunter Island in 1830 (see above). 
Tahitians, too, were in Sydney's multi-racial crews. In 1816, four were on the Endeavour for Kangaroo Island (Cumpston 1970:42). When the Perseverance left for Kangaroo Island on July 21 1824, there were four Maori and two Tahitians in a crew of 21 (Cumpston 1970:69). In 1838, 30 Maori made up a third of the men in 15 whaleboat crews racing at Hobart, afterwards performing a haka for spectators (Morton 1982:169). For such men, the arrival of European commerce in the Pacific opened a new world of opportunity.

On both sides of the Tasman, the domestic comfort and sexual services provided by women was an important aspect of the relationship between native people and sealers and whalers. We have seen how adversely this impacted on Aborigines. There was also a major impact on Maori communities, although the trajectory of the native and newcomer relationship was very different. As in Bass Strait, Maori women were at first traded only for the sealing or whaling season, the men returning to Sydney in the off-season. Later, this changed to permanent relationships as men stayed throughout the year, cultivating gardens or living with their wives' relations. In 1844, Tuckett estimated that between Banks Peninsula and Riverton, 'two-thirds of the native women, who are not aged, are living with European men' (Hocken 1898:223). In northern Hawke's Bay, many of today's Maori families have whalers' names.

Tasmanian Aborigines were killed or removed from their land, and women bartered, sold or stolen (Ryan 1977). Maori tribes, on the other hand, remained on their land and in many cases incorporated the newcomers into tribal society and whakapapa, especially when women were from chiefly families, as in the case of Puna (see Anderson 1991:7). This is not to say that killings did not take place. Chaseland himself was involved, as we have seen, but where Maori could set aside Codfish Island as a home for sealers, or in Hawke's Bay insist on rent from whaling stations, they certainly had more power.

In the history of European expansion, men of Aboriginal descent working in the New Zealand sealing and whaling industries have personal histories at the edge of a fraught and often bloody European/native relationship. Yet in other ways, they were like the men they worked with, runaway or discharged convicts and their sons, ex-seamen who as likely as not had jumped ship, adventurers or men simply on the run from another life. All were looking for economic opportunity and many also escape from a past. All made their way in an environment new to them, where what counted were experience and skill and personal qualities. In shortcomings and achievements, Chaseland, Morrison, Tomlins and Harrington reflect sealer and whaler culture of the time. While they did not escape the labels 'half-caste' or 'black', they made the best of opportunities at Australasia's early maritime frontier, and so played a part in social, economic and ultimately political transformations of the time and place.

\section{Acknowledgements}

I would like especially to acknowledge and thank Atholl for his good company when we were students at Otago University in the early '70s. When the rest of us heard that typewriter clacking away into the small hours in the back office at Cumberland Street, we were not to know that his thesis on the Black Rocks middens was to begin a stellar contribution to New Zealand and Pacific archaeology and history.

This paper results from research on the New Zealand shore-whaling industry carried out with Ian Smith of the University of Otago and supported by the Royal Society of New Zealand's Marsden Fund. For particular help, I would like to thank: the late Terry Arnott, Heritage Branch, 
South Australian Department of Environment and Heritage; Ian Church, Port Chalmers; John Hall-Jones, Invercargill; June McDougall, Dunedin; Tony Monteith and Patrick Parsons, Napier; Mike Nash, Parks and Wildlife Service, Tasmania; Lynette Russell, Monash University, Melbourne; Mark Staniforth, Flinders University, Adelaide; Auckland Museum library staff. Peter Quin prepared the figures.

\section{References}

Anderson, A.J. 1991. Race Against Time. Dunedin: Hocken Library.

Beaglehole, J.C. 1961. The Journals of Captain James Cook on His Voyages of Discovery. The Voyage of the Resolution and Endeavour 1772-1775. Cambridge: Cambridge University Press for the Hakluyt Society.

Beattie, H. 1919. Traditions and legends. Collected from the natives of Murihiku. (Southland, New Zealand). Journal of the Polynesian Society 28: 212-225.

Beattie, H. 1948. Otago Place Names. Dunedin: Otago Daily Times and Witness Newspapers.

Begg A.C. and N.C. Begg 1979. The World of John Boultbee. Christchurch: Whitcoulls.

Belich, J. 1996. Making Peoples; a history of the New Zealanders. Auckland: Allen Lane and Penguin.

Birmingham, J. 1992. Wybalenna: the archaeology of cultural accommodation in nineteenth century Tasmania. Sydney: Australian Society for Historical Archaeology.

Chamberlain, S. 1989. Sealing, whaling and early settlement of Victoria; an annotated bibliography of historical sources. Victoria Archaeological Survey Occasional Report 29.

Church, I. In Press. Gaining a foothold, historical records of the east Otago coast, 1770 to 1839.

Cumpston, J.S. 1970. Kangaroo Island 1800-1836. Canberra: Roebuck Society Publication No 1.

Cumpston, J.S. 1977. Shipping Arrivals and Departures Sydney, 1788-1825. Canberra: Roebuck Society Publication No 22.

Dinwiddie, W. 1916. Old Hawkes Bay. Napier: Dinwiddie, Walker and Co.

Dunderdale, G. [1898]. The Book of The Bush. London: Ward Lock.

Feilding, T.H. (ed) 1875. Wise's Directory of New Zealand for the Years 1875-76. Dunedin: Henry Wise and Co.

Hainsworth, D.R. 1972. The Sydney Traders; Simeon Lord and his contemporaries 1788-1821. Melbourne: Cassell Australia.

Hall-Jones, F.G. 1944. Kelly of Inverkelly. Invercargill: Southland Historical Committee and H. and J. Smith.

Hall-Jones, F.G. 1945. Historical Southland. Invercargill: Southland Historical Committee and H. and J. Smith.

Hall-Jones, J. 1990. Chaseland, Thomas. In The Dictionary of New Zealand Biography (Vol. 1), p. 80. Wellington: Allen and Unwin and the Department of Internal Affairs.

Hocken, T.M. 1898. Contributions to the Early History of New Zealand (Settlement of Otago). London: Sampson Low, Marston.

Howard, B. 1940. Rakiura; a history of Stewart Island, New Zealand. Dunedin: Reed, for the Stewart Island Centennial Committee.

Ingram, C.W.N. 1984. New Zealand Shipwrecks 1795-1982, Sixth edition. Wellington: Reed.

Joseph, F.A. 1903. The old whaling station on Taieri Island. The Otago Witness 22 April 1903.

Lambert, T. 1925. The Story of Old Wairoa. Dunedin: Coulls, Somerville, Wilkie.

Langlands, L. 1906. Reminiscences of early days. The Otago Witness 12 December 1906.

Ling, J.K. 1999. Exploitation of fur seals and sea lions from Australian, New Zealand and adjacent subantarctic islands during the eighteenth, nineteenth and twentieth centuries. Australian Zoologist 31:323-350.

McNab, R. 1907. Muribiku and the Southern Islands. Invercargill: William Smith. 
McNab, R. 1913. The Old Whaling Days. Wellington: Whitcombe and Tombs.

Mantell, W.B.D. 1872. On moa beds. Transactions and Proceedings of the New Zealand Institute 5:94-97.

Middleton, A. 2006. Two Hundred Years on Codfish Island (Whenuahou). Invercargill: Department of Conservation.

Morton, H. 1982. The Whale's Wake. Dunedin: University of Otago Press.

Nash, M. 2003. The Bay Whalers; Tasmania's shore-based whaling industry. Woden: Navarine Publishing.

Nicholson, I.H. 1983. Shipping Arrivals and Departures, Tasmania, Vol. 1, 1803-1833. Canberra: Roebuck Society Publication No 30.

Nobbs, R. 1988. Norfolk Island and its First Settlement 1788-1814. North Sydney: Library of Australian History.

Plomley, N.J.B. (ed) 1966. Friendly Mission; the Tasmanian journals and papers of George Augustus Robinson 1829-1834. Tasmania: Tasmanian Historical Research Association.

Plomley, N.J.B. and K.A. Henley 1990. The sealers of Bass Strait and the Cape Barren Island community. Tasmanian Historical Research Association Papers and Proceedings 37:37-127.

Prickett, N.J. 2002. The Archaeology of New Zealand Shore Whaling. Wellington: Department of Conservation.

Richards, R. 1995. Murihiku Re-viewed; a revised history of southern New Zealand from 1804 to 1844. Wellington: Lithographic Services.

Roberts. W.H.S. 1909. Maori nomenclature; early history of Otago. The Otago Witness 10 March 1909.

Ryan, L. 1996. The Aboriginal Tasmanians. Sydney: Allen and Unwin.

Shortland, E. 1851. The Southern Districts of New Zealand. London: Longman, Brown, Green and Longmans.

Smee, C.J. and J. S. Provis 1981. The 1788-1820 Associations Pioneer Register, 2nd edition, Vol. 1 (unpaginated). Sydney: The 1788-1820 Association.

Smith, I.W.G., 2002. The New Zealand Sealing Industry. Wellington: Department of Conservation.

Starke, J. (ed) 1986. Journal of a Rambler; the journal of John Boultbee. Auckland: Oxford University Press.

Steven, M. 1965. Merchant Campbell 1769-1846. Melbourne: Oxford University Press.

Tipping, M. 1988. Convicts Unbound; the story of the Calcutta convicts and their settlement in Australia. Ringwood: Viking O'Neil.

Tod, F. 1982. Whaling in Southern Waters. Dunedin: Published by the author.

Townrow, K. 1997. An Archaeological Survey of Sealing and Whaling Sites in Victoria. Heritage Victoria and Australian Heritage Commission.

Wakefield, E.J. 1845. Adventure in New Zealand. London: John Murray.

Wakefield, E.J. 1848. The Hand-book for New Zealand. London: John W. Parker. 